Travaux du Muséum National d'Histoire Naturelle «Grigore Antipa»
Vol. 61 (1)

pp. 19-21

\title{
Agrilus (Uragrilus) guerini: a New Species for the Romanian Fauna (Coleoptera: Buprestidae)
}

\author{
Cosmin-Ovidiu MANCI ${ }^{1, *}$, Adrian RUICĂNESCU²
}

\begin{abstract}
${ }^{1}$ S.E.O.P.M.M. Oceanic-Club, Constanța, Romania
${ }^{2}$ Institute of Biological Research, Cluj-Napoca branch of the National Institute of Research and Development for Biological Sciences, 48 Republicii Str., 400015 Cluj-Napoca, Romania *corresponding author, e-mail: cosminom@gmail.com
\end{abstract}

Received: April 5, 2018; Accepted: June 5, 2018; Available online: June 27, 2018; Printed: June 30, 2018

\begin{abstract}
Agrilus guerini Lacordaire is recorded for the first time in Romania, in Southern Transylvania. The occurrence of this species in Romania was expected, as it is present in neighbouring countries. A short description, some aspects of biology and ecology, and a distribution map of this species in Romania are given.
\end{abstract}

Keywords: Agrilus guerini, Buprestidae, first record, Romania

The presence of Agrilus guerini Lacordaire, 1835 in Romania was expected, as it occurs in almost all of the surrounding countries. One specimen labelled "Erdély", which means Transylvania, was found in the collections of the Natural History Museum of Budapest, but it lacked any other details. In 27.V.2017, Cosmin Ovidiu Manci collected 3 specimens (all females) of A. guerini and observed several others near Bretea Mureșană, at the edge of Brănișca Forest (N 45.9378\% E 22.7351을 cca $200 \mathrm{~m}$ a.s.l., Hunedoara county). This is the first confirmed record of this species in Romania (fig. 1). The specimens were observed flying around or resting on the leaves of Salix cinerea. All specimens occurred only around this particular bush, which had dead branches (fig. 3B). Together with A. guerini, several specimens of A. viridis (Linnaeus, 1758) were also collected. The biotope of the collected specimens was a wet hayfield with willow and poplars bushes bordered by cultivated land, on one side (fig. 3A), at the edge of a mature forest. The collected specimens are preserved in the private collections of the authors ( 2 females in the collection of Cosmin Manci, Iași, Romania - CMCI and one female in the collection of Adrian Ruicănescu, Cluj, Romania - ARCC).

Agrilus (Uragrilus) guerini (fig. 2C) is one of the largest Agrilus species in Europe, that means it is about or more than $10 \mathrm{~mm}$ in length. The colour is dark with greenish or bluish lustre. Six white spots are present on the elytra: two in the humeral area, two in the mid-length and two in the posterior third. In Romania, the species can easily be confused only with Agrilus (Uragrilus) ater Linnaeus, 1767 (fig. 2A) and A. (Anambus) biguttatus Fabricius, 1777 (fig. 2B) (Panin et al., 2015). The most striking character for recognising this species is the apices of the elytra, which are divergent, very sharp and prolonged like the shape of swallowtail (fig. 2). A. ater has short, pointed apices of the elytra, while A.biguttatus has the apices rounded.

Larvae of Agrilus guerini develop as primary or secondary pests in the branches of different species of willows (Salix caprea, S. purpurea, S. incana, $S$. alba, S. cinerea, S. aurita) (Curletti, 1994) where they bore tunnels under the bark, 


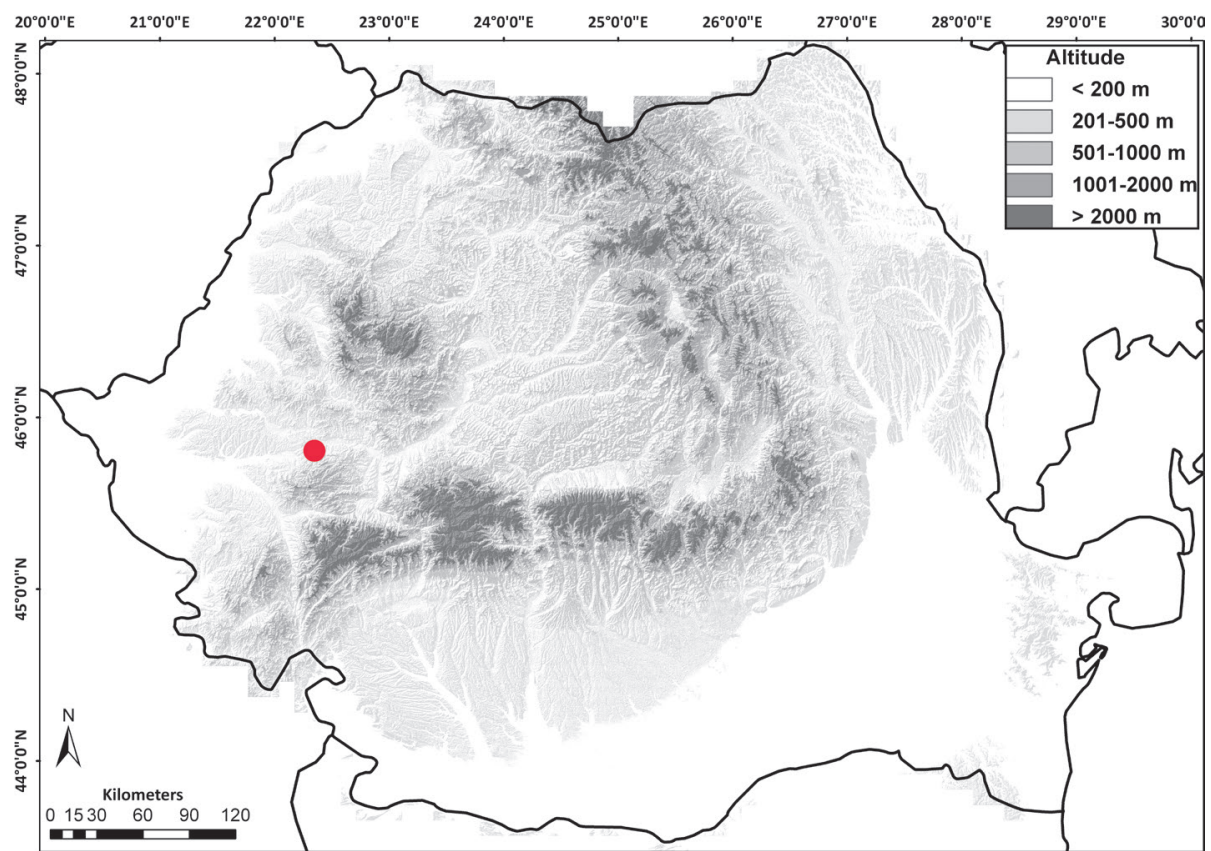

Fig. 1 - The location of the first record of Agrilus guerini in Romania

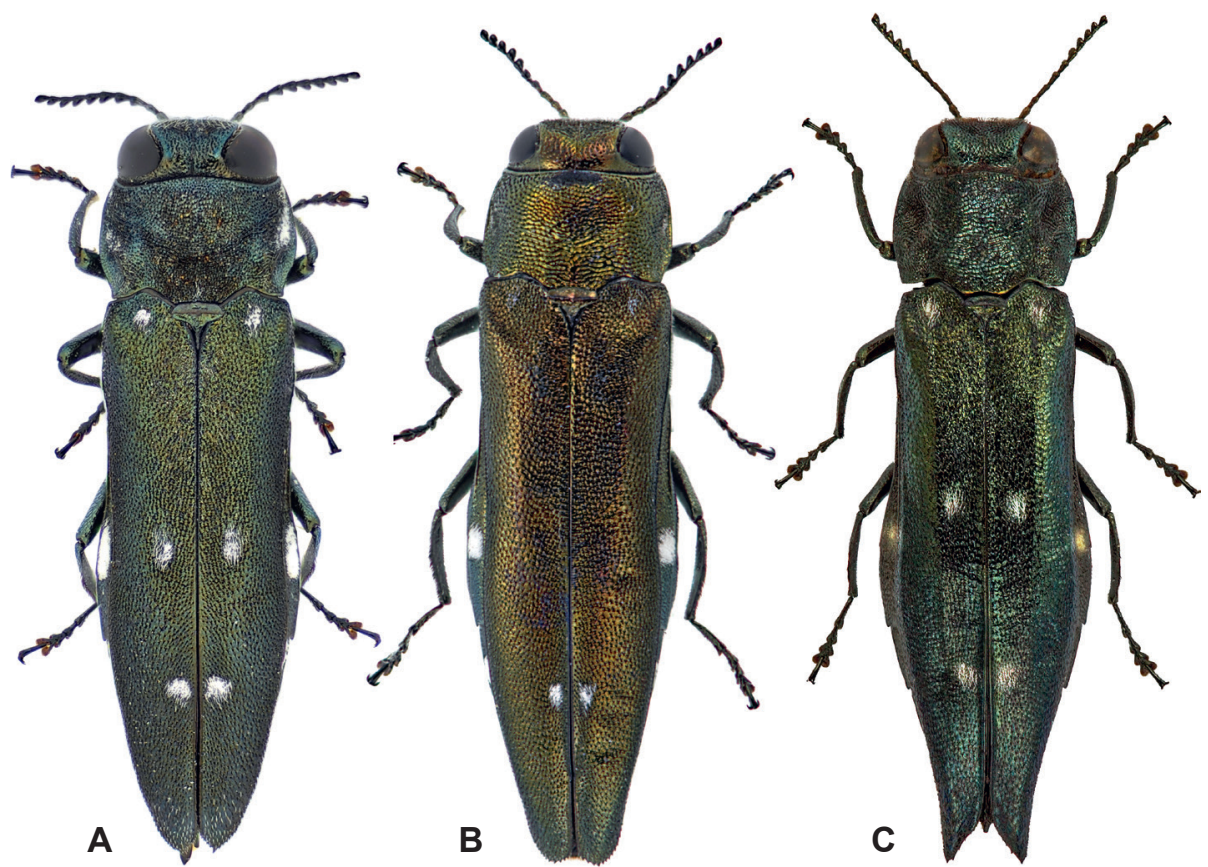

Fig. 2 - A. Agrilus (Uragrilus) ater (L.) (photo: A. Ruicănescu), B. Agrilus (Anambus) biguttatus (F.) (photo: A. Ruicănescu) and C. Agrilus (Uragrilus) guerini Lac. (photo: C. O. Manci). 

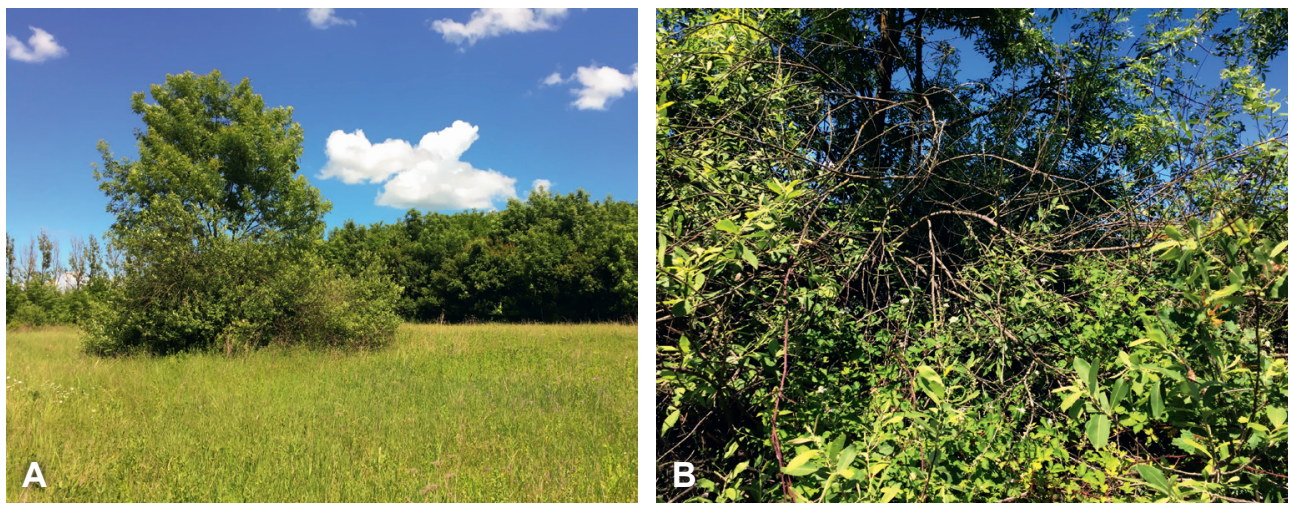

Fig. 3 - Aspects of the biotope where Agrilus guerini was recorded: A. general view, B. detail of Salix cinerea where from the specimens were collected (photo: C. O. Manci).

feeding especially in the cambium. The larval stage lasts for 2-3 years. Probably, they pupate in August or September, for 2-3 weeks and the young adults remain in the pupal cell and hibernate there. The adults occur in April-July, on the leaves or bark of willows. No serious damage caused by this species have been reported (Bílý, 2002).

Agrilus guerini is an European, meso-xerotermophilous element (Ruicănescu, 2013; Panin et al., 2015). It is known from almost all Europe, close to Romania: Czech Republic, Hungary, Serbia, Slovakia and Ukraine, missing only in Bulgaria and Moldova (Löbl \& Löbl, 2016).

Our data represent the first confirmed record of this insect in Romania. The presence of this species in other regions of Romania, at least in Banat and Crișana (Western Romania), is likely.

\section{ACKNOWLEDGMENTS}

Fieldwork would have been impossible without the help of Călin Hodor from Wildlife Management Consulting. A. Ruicănescu's work was funded by the Romanian Ministry of Education within the Romanian National Research Program 30N/2018 Biodivers 2. We also express our gratitude to Chris Raper for reviewing the manuscript.

\section{REFERENCES}

BÍLÝ, S. (2002) Summary of the bionomy of the Buprestid beetles of Central Europe (Coleoptera: Buprestidae). Acta Entomologica Musei Nationalis Pragae, Suppl. 10: 1-104.

CURLETTI, G. (1994) I Buprestidi d'Italia. Monografie Di Natura Bresciana, 19: 1-318. (in Italian)

LÖBL, I., D. LÖBL (2016) Catalogue of Palaearctic Coleoptera. Volume 3. Scarabaeoidea, Scirtoidea, Dascilloidea, Buprestoidea, Byrrhoidea. Revised and updated edition. Leiden; Boston: Brill, 983pp. https://doi.org/10.1163/9789004309142

PANIN, S., N. SĂVULESCU, A. RUICÃNESCU (2015) Coleoptera-Buprestidae, In: Fauna României, Insecta, vol. X, fasc. 7, Academia Română, Bucharest, 388 pp. (in Romanian)

RUICĂNESCU, A. (2013) The Jewel Beetles of Romania (Coleoptera: Buprestidae). Series Faunistica No. 108. Pensoft Publisher, Sofia-Moskow, 203 pp. 